\title{
GAMIFIKASI UNTUK PENDIDIKAN: PEMBELAJARAN KIMIA YANG MENYENANGKAN PADA MASA PANDEMI COVID-19
}

\section{Achmad Lutfi ${ }^{*}$, Nur Qurrotur Aini ${ }^{2}$, Nurul Amalia ${ }^{3}$, Putri Amiratul Umah ${ }^{4}$, Maissy Diana Rukmana ${ }^{5}$}

1,2,3,4,5, Jurusan Kimia, Universitas Negeri Surabaya, Indonesia

*Corresponding Author: achmadlutfi@unesa.ac.id

\section{ART I CLE I N F O}

Article history:

Received August 13, 2021

Revised August 15, 2021

Accepted September 26, 2021

Available online October 25, 2021

Kata Kunci:

Pandemi Covid 19,

Pembelajaran Kimia,

Permainan

Keywords:

Covid 19 Pandemic,

Chemistry Learning, Games

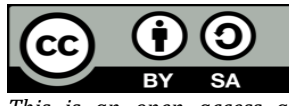

This is an open access article under the CC BY-SA license.

Copyright (C) 2021 by Author. Published by Universitas

Pendidikan Ganesha.

\begin{abstract}
A B S T R A K
Pembelajaran kimia secara daring dikeluhkan karena terasa bosan oleh peserta didik sehingga perlu upaya agar tercipta pembelajaran yang menyenangkan. Tujuan penelitian ini untuk menganalisis efektifitas penggunaan permainan bersarana smartphone atau computer sebagai media pembelajaran kimia di era pandemi covid 19. Jenis penelitian ini merupakan penelitian eksperimen dengan desain the posttest-only control group. Penelitian telah dilakukan terhadap empat kelas peserta didik SMA, pembelajaran kimia dilakukan dengan menggunakan permainan sebagai media pembelajaran. Sebelum pembelajaran dilakukan pretest, dan setelah pembelajaran secara daring dilakukan posttest dan pemberian angket. Skor hasil pembelajaran dianalisis dengan bantuan program SPSS untuk mengetahuan kenaikan hasil belajar dan tingkat ketuntasannya, sedangkan hasil angket disajikan dalam prosentasi dan dianalisi secara deskripsi. Hasil penelitian menunjukkan ada perbedaan antara hasil belajar sebelum (pretest) dengan hasil belajar sesudah pembelajaran (posttest), ketuntasasan dapat tercapai dan peserta didik merasakan pembelajaran kimia dengan permainan sebagai media pembelajaran dapat memberikan semangat belajar dan dapat menghibur diri, dirasakan menyenangkan selama pembelajaran. Peserta didik mendukung penggunaan permainan sebagai media pembelajaran selama belajar di rumah, sehingga permainan dapat digunakan sebagai alternatif media pembelajaran kimia pada masa pandemi covid-19.
\end{abstract}

\section{A B S T R A C T}

Learning chemistry online is complained about because it feels bored by students so that efforts are needed to create fun learning. The purpose of this study is to measure the effectiveness of using smartphone or computer games as learning media for Chemistry in the era of the COVID-19 pandemic. The study was conducted in four classes of high school students in different cities in East Java. Chemistry learning was carried out using game as a learning medium. Pretest was conducted before learning while posttest and questionnaire were given after online learning. The learning outcome scores were analyzed with SPSS program to determine the increase in learning outcomes and the level of completeness, while the results of the questionnaire were presented in percentage and analyzed descriptively. The results showed that there was a difference between learning outcomes before and learning outcomes after learning, completeness could be achieved and students felt that learning Chemistry with game as a learning medium could provide enthusiasm for learning and could entertain themselves. Besides, the students felt fun during online learning. The students support the use of games as learning media during learning at home, so that game can be used as an alternative to learning media for Chemistry during the covid-19 pandemic.

\section{PENDAHULUAN}

Pendidikan dan pembelajaran tetap harus dilakukan walaupun dalam kondisi yang sulit termasuk adalah pandemic covid 19. Adanya Covid-19 pertama kali teridentifikasi dari Kota Wuhan di China, wabah tersebut telah membawa perubahan sangat besar terhadap seluruh aspek kehidupan termasuk pendidikan (Gopal et al., 2021; Green et al., 2020). Pada awal Maret 2020, kasus pertama pasien positif Covi-19 di Indonesia mulai muncul dengan cepat bertambah dan meluas ke penjuru Nusantara 
(Pinasti, 2020; Yulianingsih et al., 2021). Berdasarkan WHO, Covid-19 (Coronavirus- 2019) dinyatakan sebagai kedaruratan kesehatan masyarakat yang menjadi pusat perhatian internasional Sebanyak lebih dari 200 negara terkena wabah virus korona termasuk Indonesia (Jamie, 2020; Pinasti, 2020). Pemerintah berupaya dalam memutus rantai penyebaran Covid-19 dengan menetapkan beberapa kebijakan seperti stay at home, physical dan social distancing dengan harapan penyebaran Covid-19 ini segera selesai di Indonesia (Arief Kresna dan Juni Ahyar, 2020; Lapitan et al., 2021; Lau et al., 2020). Dengan adanya kebijakan tersebut, proses belajar mengajar yang biasanya dilakukan dengan tatap muka mengalami perubahan dilakuan secara mandiri dan jarak jauh secara daring termasuk pada pembelajaran kimia. Kimia merupakan salah satu materi pembelajaran yang wajib bagi peserta didik jurusan IPA di sekolah menengah atas (Kartini \& Putra, 2020; Sudiana et al., 2019). Ilmu kimia merupakan ilmu yang mempelajari struktur materi dan perubahan-perubahan yang dialami materi dalam fenomena alamiah maupun dalam eksperimen (Budiariawan, 2019; Nugrahaeni et al., 2017; Wasonowati, 2014). Oleh karena itu, peserta didik harus mampu memenuhi kompetensi dasar dalam pembelajaran kimia.

Namun kenyataannya, pada proses pembelajaran kimia banyak peserta didik mengalami kesulitan belajar. Data yang diperoleh pada pembelajaran kimia di sejumlah sekolah tampak kurang atraktif, sampai-sampai peserta didik merasa bosan, dalam proses pembelajaran kimia membuat suasana kelas cenderung pasif. Kondisi seperti itu yang melahirkan kejenuhan, dan kejengkelan, sehingga minat, atensi dan dorongan peserta didik dalam proses pembelajaran menjadi buruk (Ristiyani \& Bahriah, E., 2016). Berdasarkan angket kepada guru kimia SMA, hal itu pula menjadi masalah sukarnya materi kimia untuk dipahami sehingga menambah beban pengajar dalam menjelaskan materi kimia. Dengan adanya pandemi ini peserta didik diharuskan untuk belajar dari rumah, mengakibatkan guru mengalami kesulitan mencari metode dan media yang tepat untuk menjelaskan materi ini agar peserta didik menjadi paham dan menyenagkan. Kreativitas seorang guru dalam proses pembelajaran secara daring tampaknya benar-benar diperlukan dan akan berdampak pada kesuksesan suatu target pembelajaran. Karakteristik ilmu kimia merupakan sebagian materi yang abstrak dan penuh dengan konsep matematika, serta diperlukan praktikum yang tidak mudah maka perlu media yang dapat digunakan memudahkan peserta didik memahami konsep (Cahyana et al., 2017). Data awal penelitian terhadap 730 peserta didik yang diminta pendapat tentang frekuensi bermain diperoleh data $96 \%$ peserta didik pernah bermain dan yang menyatakan tidak pernah bermain sebesar 4\%, artinya sebagian besar peserta didik menyukai permainan walaupun berbeda-beda tingkat berdasar kesempatannya. Data lain yang diperoleh bahwa permainan yang berbantuan smartphone lebih disukai $(66,1 \%)$ dibanding permainan berbantuan komputer $(33,9 \%)$. Jika dibiarkan permasalahan tersebut akan memberikan dampak buruk pada pembelajaran kimia.

Solusi untuk mengatasi permasalahan tersebut yaitu diperlukan media pembelajaran yang cocok dan disenangi oleh peserta didik. Salah satunya media permainan. Penggunaan permainan akan membuat peserta didik merasa senang dan membuat suasana belajar menjadi bahagia (Musi et al., 2017; Putrantana et al., 2020; Zahro \& Lutfi, 2021). Permainan harus didesain sebaik mungkin agar peserta didik tertarik sehingga dapat memahami materi pelajaran dan memiliki semangat belajar (Musi et al., 2017; Witasari \& Wiyani, 2020). Penyampaian materi pembelajaran dengan menggunakan permainan merupakan salah satu upaya untuk menciptakan pembelajaran yang menyenangkan, tidak membosankan, dan mudah dipahami oleh peserta didik (Carrillo et al., 2019). Selain itu permainan dapat melibatkan peserta didik aktif dalam proses pembelajaran. Belajar tidak hanya membaca dan mendengarkan penjelasan dari guru melainkan dengan cara bermain pun dapat terjadi proses belajar. Permainan dapat dikaitkan dengan pengalaman belajar melalui desain yang sesuai (Gustiana \& Puspita, 2020; Pratama et al., 2021). Strategi permainan yang digunakan dalam pendidikan meliputi skenario, mencocokan, menantang, dan pemecahan masalah, maka pembelajaran berbasis permainan memungkinkan peserta didik membangun pengetahuan dari ambigu, coba-coba dan mengasimilasi pengetahuan baru (Nordby et al., 2016). Penggunaan permainan dapat untuk merayu dan memotivasi peserta didik untuk mencapai tujuan tertentu dalam hal ini tujuan pembelajaran yang direncanakan disebut gamifacation (Carrillo et al., 2019).

Beberapa temuan sebelumnya menyatakan dalam permainan dapat juga menunjukkan tercapainya tujuan pembelajaran dan tercapainya ketuntasan belajar (Bai et al., 2020). Permainan memiliki pengaruh yang kuat terhadap pencapaian tujuan (Pitaloka et al., 2021). Dalam permainan yang terdapat tantangan, bermakna bagi peserta didik dan terkait dalam kehidupan nyata peserta didik dapat memudahkan tercapai tujuan (Baptista \& Oliveira, 2019). Permainan sebagai media pembelajaran mempunyai keunggulan, yaitu dapat menyenangkan, ingin terus bermain, dan memotivasi untuk belajar (Huang \& Hew, 2018). Permainan sebagai media pembelajaran dapat meningkatkan hasil belajar dan motivasi belajar peserta didik (Safitri et al., 2018). Pendidikan kecendrungan memilih kegiatan yang mengarah pada tujuan dan mengarah pada keberhasilan, sehingga permainan yang dikembangkan untuk 
pembelajaran kimia harus memenuhi tercapainya tujuan pembelajaran. Motivasi dapat terjadi ketika belajar menggunakn permainan, sejumlah peserta didik motivasinya terorientasi pada tujuan-tujuan pembelajaran (learning goals) atau penuntasan tujuan (mastery goals). Dalam permainan juga memberikan kesempatan peserta didik membenarkan kekeliruan atau memperbaiki pekerjaan yang salah, dan akan membantu menghilangkan rasa cemas peserta didik sehingga dapat melakukan yang terbaik. Tujuan penelitian ini yaitu untuk menganalisis efektifitas penggunaan permainan bersarana smartphone atau computer sebagai media pembelajaran kimia di era pandemi covid 19.

\section{METODE}

Jenis penelitian ini merupakan penelitian eksperimen dengan desain the posttest-only control group, menggunakan empat kelompok dan tidak ada kelompok kontrol. Penelitian dilakukan pada empat kelas di sekolah yang berbeda kota di Jawa Timur. Keempat kelas ditentukan secara acak dan dilakukan pembelajaran kimia dengan menggunakan permainan sebagai media pembelajaran. Waktu penelitian pada April - Mei 2020 dilakukan secara daring. Sebelum pembelajaran dilakukan pretest dan setelah pembelajaran dengan menggunakan permainan sebagai media pembelajaran dilakukan posttest, pada keempat kelompok menggunakan permainan yang berbeda. Data yang diperoleh berupa skor hasil belajar, dihitung rata-rata. Skor rata-rata pretest dibandingkan dengan skor posttest menggunakan uji t berpasangan dengan bantuan program SPSS dan tingkat ketuntasan klasikal skor pretest dengan posttest berdasarkan kriteria lebih besar atau sama dengan 80\% ketuntasan individual. Angket yang digunakan berupa skala Guttman ('ya' atau 'tidak') dianalisis menjadi persentasi (\%) dengan deskripsi kuantitatif, minimal kriteria yang dicapai adalah kategori 'baik'. Kriteria angket respn peserta didik disajikan pada Tabel 1.

Tabel 1. Kriteria Angket Respon

\begin{tabular}{ccc}
\hline No & Persentase & Kriteria \\
\hline 1 & $81 \%-100 \%$ & Sangat Baik \\
2 & $61 \%-80 \%$ & Baik \\
3 & $41 \%-60 \%$ & Cukup \\
4 & $21 \%-40 \%$ & Buruk \\
5 & $0 \%-20 \%$ & Buruk sekali \\
\hline
\end{tabular}

\section{HASIL DAN PEMBAHASAN}

Hasil

Hasil berajar berasal dari skor pretest dan skor posttes, dengan bantuan program SPSS dilakukan perhitungan uji normalitas Kolmogorov-Smirnov pada skor pretest dan posttest, serta harga $\mathrm{t}$ uji berpasangan. Hasil yang diperoleh bahwa skor pretest dan skor posttest berdistribusi normal karena sig lebih besar dari 0,05 sehingga dapat dilakukan uji t berpasangan. Hasil menunjukan pada skor keempat kelas telah memenuhi persyaratan untuk dilakukan uji t berpasangan. Berdasarkan uji t berpasangan antara rata-rata skor pretest dengan skor posttest dan menunjukkan keempat kelas harga t hitung lebih besar dari pada harga $t$ tabel pada taraf signifikansi $5 \%$, artinya pada keempat kelompok terjadi perbedaan skor yang nyata antara sebelum dan sesudah pembelajaran menggunakan permainan sebagai media pembelajaran. Hasil lengkap disajikan pada Tabel 2.

Tabel 2. Hasil Skor Prestest dan Posttest

\begin{tabular}{|c|c|c|c|c|c|c|c|c|c|}
\hline Kel & $\begin{array}{c}\text { Nama } \\
\text { Permainan }\end{array}$ & Kondisi & $\begin{array}{c}\text { Skor } \\
\text { rata- } \\
\text { rata }\end{array}$ & $\begin{array}{c}\text { Skor } \\
\text { terendah }\end{array}$ & $\begin{array}{c}\text { Skor } \\
\text { tertinggi }\end{array}$ & $\begin{array}{l}\text { Asymp. } \\
\text { Sig. (2- } \\
\text { tailed) }\end{array}$ & $\begin{array}{l}\text { Harga t } \\
\text { hitung }\end{array}$ & $\begin{array}{c}\text { Jumlah } \\
\text { peserta } \\
\text { didik }\end{array}$ & $\begin{array}{c}\% \\
\text { tuntas }\end{array}$ \\
\hline \multirow{2}{*}{1} & Hydrocarbon & Pretest & 44,19 & 32 & 55 & 0.071 & \multirow{2}{*}{21,713} & 27 & 0 \\
\hline & Advenacure & Posttest & 83,41 & 73 & 100 & 0.218 & & 27 & 92,6 \\
\hline \multirow{2}{*}{2} & Adventure of & Pretest & 40,74 & 0 & 80 & 0.337 & \multirow{2}{*}{12.753} & 27 & 7,4 \\
\hline & element & Posttest & 87,40 & 50 & 100 & 0,153 & & 27 & 88,9 \\
\hline \multirow{2}{*}{3} & & Pretest & 23,90 & 6,25 & 62,5 & 0.230 & \multirow{2}{*}{19.390} & 27 & 0 \\
\hline & Red and $O x$ & Posttest & 80,80 & 43,75 & 100 & 0,153 & & 27 & 85,2 \\
\hline \multirow{2}{*}{4} & Chemy Shooter & Pretest & 61,00 & 40 & 85 & 0,200 & \multirow{2}{*}{14.343} & 15 & 20 \\
\hline & & Posttest & 84,00 & 70 & 100 & 0,200 & & 15 & 80,0 \\
\hline
\end{tabular}


Ketuntasan klasikal tertinggi dicapai pada kelompok 1 pada pembelajaran hidrokarbon kemudian berturut-turut kelompok 2 pada pembelajaran unsur, kelompok 3 pada pembelajaran redoks, dan kelompok 4 pada pembelajaran asam basa. Terendah ketuntasan pada kelompok 4 pada pembelajaran asam basa, yaitu 80\%. Paling rendahnya ketuntasan pada kelompok 4 dimungkinkan karena permainan dengan bantuan laptop sedangkan yang lainnya dengan bantuan spartphone, hal ini sesuai hasil angket yang menyatakan sebagian besar peserta didik lebih suka bermain berbantuan smartphone (66,1\%). Permainan Hydrocarbon Advantures untuk pembelajaran senyawa karbon, diperoleh jawaban peserta didik terhadap pernyataan didapatkan respon yang sangat baik. Hal ini dapat dilihat dari respon peserta didik terhadap pernyataan bahwa mampu memainkan permainan dengan lancer, mendapatkan respon positif sebesar $82,4 \%$. Permainan mempermudah peseta didik memahami materi ditunjukkan hasil jawaban peserta didik sebesar $87,96 \%$ pernyataan setuju, sedangkan peserta didik setuju bila belajar selama covid 19 menggunakan permainan memperoleh jawaban sebesar 84,26\%.

Pada permainan Chemy Shooter untuk pembelajaran asam basa, terhadap pernyataan 'permainan ini membuat saya tertantang'memperoleh tanggapan 93,33\% setuju, dan terhadap pernyataan 'saya merasa termotivasi untuk belajar ketika belajar dengan permainan' memperoleh tanggapan sebesar 86,67\%. Artinya peserta didik tertantang dan berkeinginan untuk belajar kimia dengan bermain. Pada pernyataan 'permainan ini membantu saya belajar sendiri meski tidak terjadwal pelajaran kimia' memperoleh skor tanggapan setuju sebesar 100\%. Terhadap pernyataan lainnya,'permainan ini membuat saya dapat belajar sambil bermain' memperoleh tanggapan setuju 100\%. Artinya peserta didik ketertarikan permainan karena dapat belajar dan bermain. Terhadap pernyataan 'saya tidak mengalami kesulitan dalam mengoperasikan permainan tersebut' memperoleh tanggapan 93,33\% menyetujui dan terhadap pernyataan saya tidak mengalami kesulitan dalam menginstal software permainan memperoleh tanggapan setuju 93,33\% artinya peserta didik beranggapan permainan sebagai media pembelajaran materi asam basa mudah digunakan. Peserta didik sebagian besar (83,30\% hingga 90\%) menyatakan tidak bosan bahkan menyenangkan belajar kimia dengan menggunakan permainan sebagai media pembelajaran. Hasil ini dapat menjadi solusi terhadap hasil angket pada awal penelitian yang menunjukkan bahwa peserta didik menyatakan sebesar 43,5\% merasa bosan belajar dari rumah dapat berubah menjadi 10,0\% sampai 16,7\% peserta didik yang merasa bosan

\section{Pembahasan}

Hasil penelitian yang menyatakan permainan sebagai media pembelajaran kimia mampu meningkatkan hasil belajar yang signifikansi dan mencapai hasil belajar yang baik. Media yang dirancang dengan baik dapat meningkatkan hasil belajar (Huang \& Hew, 2018). Selain itu, motivasi dapat terjadi ketika belajar menggunakan permainan, sejumlah peserta didik motivasinya terorientasi pada tujuantujuan pembelajaran (learning goals) atau penuntasan tujuan (mastery goals). Dalam permainan ini juga menunjukkan tercapainya tujuan pembelajaran dan tercapainya ketuntasan belajar (Rastegarpour \& Marashi, 2012). Penggunaan tugas yang menantang, bermakna, dan berkaitan dengan kehidupan nyata pada permainan mengantarkan pada tercapainya tujuan pembelajaran dibandingkan dengan tugas-tugas lainnya. Dalam permainan yang terdapat tantangan, bermakna bagi peserta didik dan terkait dalam kehidupan nyata peserta didik dapat memudahkan tercapai tujuan. Dalam permainan juga memberikan kesempatan peserta didik membenarkan kesalahan atau memperbaiki konsep yang salah, dan akan membantu menghilangkan rasa cemas peserta didik sehingga dapat melakukan yang terbaik. Itulah keunggulan permainan, yaitu dapat menyenangkan, ingin terus bermain, dan memotivasi untuk belajar (Cadavid \& Corcho, 2018). Pemanfaatan Education Game baik secara teori maupun empirik dalam pembelajaran dapat meningkatkan hasil belajar dan aktifitas peserta didik khususnya pada mata pelajaran IPA (Nordby et al., 2016). Penggunaan permainan selama pembelajaran dapat mengatasi permasalahan peserta didik dalam memahami materi (Olsson et al., 2015). Kenaikan pengetahuan yang terjadi dikarenakan adanya proses belajar. Di mana belajar merupakan proses aktif dari peserta didik untuk merekonstruksi makna. Belajar merupakan proses mengasimilasikan dan menghubungkan pengalaman atau bahan yang dipelajarinya dengan pengertian yang sudah dimiliki, sehingga pengertiannya menjadi lebih berkembang dan itu ada dalam permainan (Sanchez et al., 2020).

Permainan dapat digunakan untuk perantara dalam belajar setelah menggunakan permainan bersarana komputer atau smartphone memberikan pengaruh positif dalam peningkatkan hasil belajar peserta didik (Budiariawan, 2019; Yunitasari \& Agustini, 2013). Pembelajaran kimia yang menyangkut aspek makroskospik, mikroskopis, dan simbolik dapat dibantu dengan permainan bersarana komputer atau handpone (Sanchez et al., 2020; She \& Annetta, 2015). Permainan Hydrocarbon Advantures untuk pembelajaran senyawa karbon, diperoleh jawaban peserta didik terhadap pernyataan didapatkan respon 
yang sangat baik. Hal ini membuktikkan peserta didik tidak menghadapi kesulitan dalam memainkan permainan sevagai media pembelajaran secara jarak jauh/daring. Suatu permainan terdapat petunjuk atau peraturan untuk peserta didik supaya tercapai tujuan pembelajaran yang diharapkan (Papadakis et al., 2020). Selain itu juga, pada multimedia sebaiknya dirancang dengan sederhana mungkin agar peserta didik dapat menggunakannya tanpa membutuhkan dengan pengetahuan yang rumit tentang multimedia (Aysolmaz \& Reijers, 2021; Tomita, 2018). Demikian pula dengan permainan sebagai media pembelajaran sebaiknya dirancang dengan sederhana supaya bisa dimainkan dengan lancar oleh peserta didik (Suryati et al., 2019). Untuk hal tersebut dapat dikatakan bahwa permainan sebagai media pembelajaran dapat digunakan dikarenakan sangat mudah dimainkan dan digunakan dalam proses belajar mengajar.

Permainan sebagai media pembelajaran menyenangkan dan menarik untuk digunakan pada saat pandemi covid-19. Hal ini membuktikkan permainan sebagai media pembelajaran mampu menaikkan keinginan peserta didik dalam belajar kimia pada saat pandemi covid-19 sehingga dapat menjadi salah satu pendukung meningkatkan hasil belajar peserta didik. Permainan sebagai media pembelajaran terdapat sejumlah kelebihan, di antaranya menyenangkan untuk dilakukan oleh peserta didik, selanjutnya dapat menghibur dan menarik untuk dimainkan. Dalam permainan memungkinkan terdapat pertisipasi yang aktif dari peserta didik untuk belajar (Zainuddin et al., 2020). Permainan mempermudah memahami materi hidrokarbon. Hal ini menunjukkan bahwa dengan kejelasan materi yang terdapat dalam media permainan dapat meningkatkan hasil belajar peserta didik dalam belajar kimia khususnya pada materi senyawa hidrokarbon. Kehadiran permainan sebagai media pembelajaran pada proses belajar mengajar bisa mengingkatkan motivasi belajar peserta didik, dan tidak menimbulkan kebosanan pada saat proses pembelajaran berlangsung, serta dapat mempermudah pemahaman suatu konsep oleh peserta didik (Kuo \& Chuang, 2016). Jadi dapat diartikan permainan sebagai media pembelajaran dapat membantu peserta didik dalam memahami pelajaran.

Terhadap permainan Adventure of Element untuk pembelajaran kimia unsur, jika pembelajaran daring menggunakan permainan karena tidak membosankan dan menyenangkan. Peserta didik merasa senang menggunakan permainan karena dapat bermain sambil belajar. Penggunaan permainan dapat menciptakan pembelajaran kimia yang mengasyikkan, dapat menciptakan pembelajaran yang didominasi oleh peserta didik, penguasaan materi, serta mendorong peserta didik belajar kimia (Zahro \& Lutfi, 2021). Permainan dapat berperan sebagai motivator bagi peserta didik untuk bermain berkali-kali. Oleh karena itu, permainan dapat dianggap sebagai alat yang memungkinkan peserta didik untuk bermain dan membantu dalam pembelajaran. Penggunaan permainan dapat membuat belajar menjadi menyenangkan dan ingin dimainkan serta pembelajaran menjadi efektif (Nordby et al., 2016). Salah satu keunggulan dari permainan sebagai media pembelajaran adalah pembelajaran menjadi seru, dan lebih menarik (Rastegarpour \& Marashi, 2012). Hal ini menunjukkan bahwa permainan dapat mendorong rasa ingin tahu peserta didik. Permainan dapat dimainkan secara individu di rumah tanpa bantuan orang lain selama pembelajaran jarak jauh. Peserta didik mampu memainkan dengan lancar mulai level awal karena telah disediakan aturan bermain secara detail. Informasi baru dalam permainan akan dihubungkan dengan informasi yang telah dimiliki pada ingatan jangka panjang. Jika informasi dianggap berguna, maka akan disimpan dalam ingatan jangka panjang yang sewaktu-waktu ingatan tersebut dapat terpanggil kembali jika dibutuhkan (Agarwal \& Saha, 2011). Permainan sebagai media pembelajaran dapat mendukung pembelajaran menjadi aktif dan mampu berkonsentrasi terhadap materi yang disampaikan dalam permainan baik dalam bentuk ringkasan maupun video yang disajikan (Rastegarpour \& Marashi, 2012).

Permainan mampu meningkatkan semangat belajar peserta didik. Peserta didik dalam menggunakan permainan merasa bersemangat walaupun berada di rumah yang menunjukkan bahwa peserta didik bersemangat dalam belajar (Zahro \& Lutfi, 2021). Motivasi peserta didik yang tinggi akan berpengaruh bagaimana cara belajar dan hasil belajar meningkat dibuktikan dari peningkatan hasil belajar dan ketuntasan klasikal yang telah dianalisis sebelumnya (Alexander et al., 2020; Guay et al., 2010). Belajar sambil bermain dapat meningkatkan semangat dan dorongan untuk belajar. Terdapat kebutuhan teknik baru untuk mengatasi kebosanan di platform online yaitu salah satunya dengan gamifikasi yang dapat dijangkau oleh peserta didik. Gamifikasi merupakan konsep yang dapat digunakan dalam pembelajaran daring/jarak jauh dan layak dieksplorasi lebih lanjut (Olsson et al., 2015). Peserta didik dapat dikatakan merasa tertarik untuk menggunakan permainan tersebut sebagai media pembelajaran yang membuat ingin memainkannya secara terus-menerus. Hal tersebut membuktikan bahwa terdapat kejelasan materi di dalam permainan. Berdasarkan hasil respon peserta didik yang didapatkan, menunjukkan bahwa permainan sebagai media pembelajaran dapat digunakan lebih mudah untk memahami materi yang dipelajari sehingga peserta didik menyukai kimia. Peserta didik merasa senang, tertarik, tidak merasa bosan ketika senang belajar kimia sambil bermain, sehingga membuat peserta didik ingin terus belajar kimia. Hal itu sama dengan secara psikologis, minat yang ada pada diri 
seorang akan sangat berpengaruh ketika mencapai sesuatu yang mereka inginkan (Dichev \& Dicheva, 2017). Apabila peserta didik memiliki perasaan senang terhadap sesuatu, maka akan berusaha secara terus menerus untuk mendapatkan dan tidak akan menyerah sebelum memperoleh apa yang diinginkan. Oleh karena itu, permainan dapat memberikan hasil yang positif pada pembelajaran.

Temuan ini diperkuat dengan temuan sebelumnya yang menyatakan adanya peningkatan hasil belajar setelah penggunaan permainan (Estiani et al., 2015; Pratama et al., 2021). Penggunaan permainan sebagai media pembelajaran kimia dapat menciptakan pembelajaran kimia yang menyenangkan peserta didik, gamifikasi dalam pendidikan sebagai media pembelajaran dapat meningkatkan keceriahan peserta didik (Olsson et al., 2015). Adanya permainan bersarana smartphone atau komuter dapat mempermudah penyajian materi baik berupa tulisan, video, animasi atau suara sehingga menarik peserta didik (Iswandari et al., 2020). Gamifikasi dipahami sebagai proses di mana mekanika dan teknik desain permainan diperluas, untuk merayu dan memotivasi pemain dalam pencapaian tujuan tertentu. Oleh karena itu, ini adalah alat yang sangat efektif yang membantu menarik perhatian peserta didik, memotivasi, membuat mereka berkomitmen pada misi dan bahkan dapat memengaruhi perilaku. Hasil dan pembahasan menunjukkan hasil belajar kimia peserta didik di empat kelompok mencapai ketuntasan klasikal juga memperlihatkan perbedaan yang signifikan antara skor pretest dengan skor posttest. Permainan yang digunakan dapat dimainkan peserta didik dengan mudah, permainan juga membuat peserta didik semangat belajar, dan peserta didik merasa permainan cocok digunakan belajar dari rumuh, serta tingkat kebosanan menurun dan sebaliknya rasa senang belajar meningkat.

\section{SIMPULAN DAN SARAN}

Gamifikasi dalam pendidikan berupa penggunaan permainan bersarana smartphone atau komputer efektif digunakan sebagai media pembelajaran kimia karena membuat peserta didik tidak bosan dan menjadikan belajar menyenangkan walaupun lama belajar di rumah, dan hasil belajar yang diperoleh dapat mencapai ketuntasan klasikal yang ditetapkan, serta peserta didik merasakan belajar kimia menjadi menarik dan hasil ini dapat dijadikan alternatif sebagai media pembelajaran kimia pada pembelajaran jarah jauh terutama masa pandemi covid 19. Para guru kimia hendaknya menggunakan permainan bersarana smartphone atau komputer sebagai media pembelajaran kimia di masa pandemi covid 19 maupun penggunaan pembelajaran secara blended learning pada topik-topik tertentu agar peserta didik dapat belajar dengan gembira sehingga dapat meningkatkan daya tahan tubuhnya.

\section{DAFTAR RUJUKAN}

Agarwal, M., \& Saha, S. (2011). Learning chemistry through puzzle based game: Atoms to Molecule. IEEE, 189-193. https://doi.org/10.1109/ICETA.2011.6112613.

Alexander, C., Wyatt-Smith, C., \& Du Plessis, A. (2020). The role of motivations and perceptions on the retention of inservice teachers. Teaching and Teacher Education, 96, 103186. https://doi.org/10.1016/j.tate.2020.103186.

Arief Kresna dan Juni Ahyar. (2020). Pengaruh Physical Distancing dan Social DistancingTerhadap Kesehatan Dalam Pendekatan Linguistik. Jurnal Syntax Transformation, 1(4), 14-18. http://jurnal.globalhealthsciencegroup.com/index.php/JPPP/article/download/83/65\%0Ahttp:/ /www.embase.com/search/

Aysolmaz, B., \& Reijers, H. A. (2021). Animation as a dynamic visualization technique for improving process model comprehension. Information and Management, 58(5), 103478. https://doi.org/10.1016/j.im.2021.103478.

Bai, S., Hew, K. F., \& Huang, B. (2020). Does gamification improve student learning outcome? Evidence from a meta-analysis and synthesis of qualitative data in educational contexts. Educational Research Review, 30, 100322. https://doi.org/10.1016/j.edurev.2020.100322.

Baptista, G., \& Oliveira, T. (2019). Gamification and serious games: A literature meta-analysis and integrative model. Computers in Human Behavior, 92, 306-315. https://doi.org/10.1016/j.chb.2018.11.030.

Budiariawan, I. P. (2019). Hubungan Motivasi Belajar Dengan Hasil Belajar Pada Mata Pelajaran Kimia. Jurnal Pendidikan Kimia Indonesia, 3(2), 103-111. https://doi.org/10.23887/jpk.v3i2.21242.

Cadavid, J. n. M., \& Corcho, A. s. F. P. (2018). Competitive programming and gamification as strategy to engage students in computer science courses. Revista ESPACIOS, 39(35). http://www.revistaespacios.com/a18v39n35/18393511.html.

Cahyana, C., Paristiowati, M., Savitri, A., \& Hasyrin, S. N. (2017). Developing and application of mobile game based learning (M-GBL) for high school students' performance in chemistry. Journal of 
Mathematics, Science and Technology Education, 13(10), 7037-7047. https://doi.org/10.12973/ejmste/78728.

Carrillo, D. ., Carcia, A. ., Laguna, T. ., Magan, G. ., Alberto, J., \& Morena, L. (2019). Using gamification in a teaching innovation project at the University of Alcalá: A new approach to experimental science practices. The Electronic Journal of E-Learning, 17(2), 93-106. https://doi.org/10.34190/JEL.17.2.03.

Dichev, C., \& Dicheva, D. (2017). Gamifying education: What is known, what is believed and what remains uncertain: A critical review. International Journal of Educational Technology in Higher Education, 14(36). https://doi.org/10.1186/s41239-017-0042-5.

Estiani, W., Widiyatmoko, A., \& Sarwi. (2015). Pengembangan Media Permainan Kartu Uno Untuk Meningkatkan Pemahaman Konsep Dan Karakter Siswa Kelas VIITema Optik. Unnes Science Education Journal, 4(1), 711-719. https://doi.org/10.15294/usej.v4i1.4974.

Gopal, R., Singh, V., \& Aggarwal, A. (2021). Impact of online classes on the satisfaction and performance of students during the pandemic period of COVID 19. Education and Information Technologies, 0123456789, 1-25. https://doi.org/10.1007/s10639-021-10523-1.

Green, J. K., Burrow, M. S., \& Carvalho, L. (2020). Designing for Transition: Supporting Teachers and Students Cope with Emergency Remote Education. Postdigital Science and Education, 2(3), 906922. https://doi.org/10.1007/s42438-020-00185-6.

Guay, F., Chanal, J., Ratelle, C. F., Marsh, H., Larose, S., \& Boivin, M. (2010). Intrinsic, identified, and controlled types of motivation for school subjects in young elementary school children. British Journal of Educational Psychology, 80(4), 711-735. https://doi.org/10.1348/000709910X499084.

Gustiana, A. D., \& Puspita, R. D. (2020). The Effect of Educative Games on the Physical Fitness of Kindergarten Children. Jurnal Pendidikan Jasmani Dan Olahraga, 5(2), 149 - 154. https://doi.org/10.17509/jpjo.v5i2.24518.

Huang, B., \& Hew, K. F. (2018). Implementing a theory-driven gamification model in higher education flipped courses: Effects on out-of-class activity completion and quality of artifacts. Computers \& Education, 125, 254-272. https://doi.org/10.1016/j.compedu.2018.06.018.

Iswandari, S. N., Copriady, J., Noer, A. M., \& Albeta, S. W. (2020). Development Of E-Modul Based On Moodle In Hydrocarbon Topic. Jurnal Edusains, 12(1), 81-88. https://doi.org/10.15408/es.v12i1.11503.

Jamie, A. H. (2020). Hand Washing Practices among Health Care Workers in Jugal Hospital, Harar, Ethiopia, 2020: In the Era of Corona Virus: Observational Study. Journal of Antivirals \& Antiretrovirals Researc, 12, 5-9. https://doi.org/10.35248/1948-5964.20.12.197.

Kartini, K. S., \& Putra, I. N. T. A. (2020). Respon Siswa Terhadap Pengembangan Media Pembelajaran Interaktif Berbasis Android. Jurnal Pendidikan Kimia Indonesia, 4(1), 12-19. https://doi.org/10.23887/jpk.v4i1.24981.

Kuo, M. ., \& Chuang, T. . (2016). How gamification motivates visits and engagement for online academic dissemination - An empirical study. Computers in Human Behavior, 55, 16-27. https://doi.org/10.1016/j.chb.2015.08.025.

Lapitan, L. D., Tiangco, C. E., Sumalinog, D. A. G., Sabarillo, N. S., \& Diaz, J. M. (2021). An effective blended online teaching and learning strategy during the COVID-19 pandemic. Education for Chemical Engineers, 35, 116-131. https://doi.org/10.1016/j.ece.2021.01.012.

Lau, L. L., Hung, N., Go, D. J., Ferma, J., Choi, M., Dodd, W., \& Wei, X. (2020). Knowledge, attitudes and practices of COVID-19 among income-poor households in the Philippines: A cross-sectional study. Journal of Global Health, 10(1), 1-11. https://doi.org/10.7189/JOGH.10.011007.

Musi, M. A., Sadaruddin, \& Mulyadi. (2017). Implementasi Permainan Edukatif Berbasis Budaya Lokal Untuk Mengenal Konsep Bilangan Pada Anak. Jurnal Pendidikan Anak Usia Dini, 1(2), 117-128. https://doi.org/10.24853/yby.1.2.117-128.

Nordby, A., Ygardslia, K., Sverdrup, U., \& Sverdrup, H. (2016). The art of gamification; teaching sustainability and system thinking by pervasive game development. Electronic Journal of ELearning, 14(3), 152-168. https://academic-publishing.org/index.php/ejel/article/view/1752.

Nugrahaeni, A., Redhana, I. W., \& Kartawan, I. M. A. (2017). Penerapan Model Pembelajaran Discovery Learning untuk Meningkatkan Kemampuan Berpikir Kritis dan Hasil Belajar Kimia. Jurnal Pendidikan Kimia Indonesia, 1(1), 23-29. https://doi.org/10.23887/jpk.v1i1.12808.

Olsson, M., Mozelius, P., \& Collin, J. (2015). Visualisation and Gamification of e-Learning and Programming Education. Electronic Journal of E-Learning, 13(6), 452-465. https://www.academicpublishing.org/index.php/ejel/article/view/1947.

Papadakis, S., Trampas, A. M., Barianos, A. K., Kalogiannakis, M., \& Vidakis, N. (2020). Evaluating the Learning Process: The "ThimelEdu" Educational Game Case Stud. CSEDU, 2, 290-298. 
https://www.scitepress.org/Papers/2020/93799/93799.pdf.

Pinasti, F. (2020). Analisis Dampak Pandemi Corona Virus Terhadap Tingkat Kesadaran. Wellnes and Healthy Magazine, 2(2), 237-249. https://doi.org/10.30604/well.022.82000107.

Pitaloka, D. L., Dimyati, D., \& Edi, P. (2021). Peran Guru dalam Menanamkan Nilai Toleransi pada Anak Usia Dini di Indonesia. Jurnal Obsesi: Jurnal Pendidikan Anak Usia Dini, 5(2), 1696-1705. https://doi.org/10.31004/obsesi.v5i2.972.

Pratama, H., Maduretno, T. W., \& Yusro, A. C. (2021). Online Learning Solution: Ice Breaking Application to Increase Student Motivation. Journal of Educational Science and Technology (EST), 7(1), 117-125. https://doi.org/10.26858/est.v7i1.19289.

Putrantana, A. B., Hariyanto, E., \& Saichudin, S. (2020). Uji Kelayakan Bahan Ajar Berbasis Multimedia Interaktif untuk Siswa Sekolah Dasar pada Materi PermainanTradisional. Jurnal Pendidikan: Teori, Penelitian, Dan Pengembangan, 5(6). https://doi.org/10.17977/jptpp.v5i6.13584.

Rastegarpour, H., \& Marashi, P. (2012). The effect of card games and computer games on learning chemistry concepts. Procedia-Social and Behavioral Sciences, 31, 597-601. https://doi.org/10.1016/j.sbspro.2011.12.111.

Ristiyani, E., \& Bahriah, E., S. (2016). Analisis Kesulitan Belajar Kimia Peserta didik di SMAN X Kota Tangerang Selatan. Jurnal Penelitian Dan Pembelajaran IPA, 2(1), 18-29. https://doi.org/10.30870/jppi.v2i1.431.

Safitri, R. W., Primiani, C. N., \& Hartini, H. (2018). Pengembangan Media Flashcard Tematik Berbasis Permainan Tradisional Untuk Kelas IV Sub Tema Lingkungan Tempat Tinggalku. Pendidikan Dasar Dan Pembelajaran, 8(1), 11. https://doi.org/10.25273/pe.v8i1.1332.

Sanchez, D., Langer, M., \& Kaur, R. (2020). Gamification in the classroom: Examining the impact of gamified quizzes on student learning. Computers \& Education, 144, 103666. https://doi.org/10.1016/j.compedu.2019.103666.

She, H. ., \& Annetta, L. . (2015). Game immersion experience: its hierarchical structure and impact on game-based science learning. Journal of Computer Assisted Learning, 31(3), 232-253. https://doi.org/10.1111/jcal.12066.

Sudiana, I. K. S., Suja, I. W., \& Mulyani, I. (2019). Analisis Kesulitan Belajar Kimia Siswa Pada Materi Kelarutan Dan Hasil Kali Kelarutan. Jurnal Pendidikan Kimia Indonesia, 3(1), 7. https://doi.org/10.23887/jpk.v3i1.20943.

Suryati, T., Suryana, \& Kusnendi. (2019). The Effect of E-Learning Based on Schoology and Student Interest to Metacognitive Thinking Skill of Vocational High School Students in Archival Subject. International Journal of Research \& Review, 6(12), 397-404.

Tomita, K. (2018). Does the Visual Appeal of Instructional Media Affect Learners' Motivation Toward Learning? TechTrends, 62(1), 103-112. https://doi.org/10.1007/s11528-017-0213-1.

Wasonowati. (2014). Penerapan Model Problem Based Learning (PBL) Pada Pembelajaran Hukum Hukum Dasar Kimia ditinjau dari Aktivitas Dan Hasil Belajar Siswa Kelas X IPA SMA Negeri 2 Surakarta Tahun Pelajaran2013/2014". Jurnal Pendidikan Kimia (JPK), 3(3). https://jurnal.fkip.uns.ac.id/index.php /kimia/article/view/4244.

Witasari, O., \& Wiyani, N. A. (2020). Permainan Tradisional untuk Membentuk Karakter Anak Usia Dini. JECED: Journal of Early Childhood Education and Development, 2(1), 52-63. https://doi.org/10.15642/jeced.v2i1.567.

Yulianingsih, W., Suhanadji, Nugroho, R., \& Mustakim. (2021). Keterlibatan Orangtua dalam Pendampingan Belajar Anak selama Masa Pandemi Covid-19. Jurnal Obsesi : Jurnal Pendidikan Anak Usia Dini, 5(2), 1138-1150. https://doi.org/10.31004/obsesi.v5i2.740.

Yunitasari, P. F., \& Agustini, R. (2013). Pengembangan Media Permainan 7 Icon Chemistry Pada Materi Pokok Ikatan Kimia Untuk Meningkatkan Hasil Belajar Peserta didik Kelas X SMA. Unesa Journal of Chemical Education, 1(3), 98-102. https://core.ac.uk/reader/230683630.

Zahro, N. M., \& Lutfi, A. (2021). Students' Well-Being and Game Implementation in Learning Chemistry in Merdeka Belajar Era. Jurnal Pendidikan Kimia Indonesia, 5(1), 34-43. https://doi.org/10.23887/jpk.v5i1.30127.

Zainuddin, Z., Chu, K., Shujahat, M., \& Perera, C. (2020). The impact of gamification on learning and instruction: A systematic review of empirical evidence. Educational Research Review, 30, 100326. https://doi.org/10.1016/j.edurev.2020.100326. 